\title{
Screening of caffeine, preservatives and antioxidants in dairy products available in Bangladesh using an RP-HPLC method
}

\author{
Md. Shahadat Hossain, Md. Samiul Islam, Subrata Bhadra and Abu Shara Shamsur Rouf
}

\begin{abstract}
Background: The aim of this current study was to investigate the presence and to determine the contents of caffeine, preservatives and antioxidants in dairy products available in Bangladesh, one of the alarming countries in terms of food security. As high as 41 marketed dairy products, of both locally and internationally manufactured, were collected from local markets of Dhaka, Bangladesh in mid-2013 and then analyzed using an RP-HPLC method to determine the contents of caffeine, benzoic acid, propylparaben, butylparaben, butylated hydroxyanisole and butylated hydroxytoluene. The evaluation was performed using a $C_{18}$ column $(150 \mathrm{~mm} \times 4.6 \mathrm{~mm}$ i.d., $5 \mu \mathrm{m}$ particle size) with a gradient flow rate of acetonitrile and diluted sulfuric acid (0.002 M) as mobile phase from ratio 15:85 to $80: 20(\% \mathrm{v} / \mathrm{v})$ at a flow rate of $2.0 \mathrm{ml} / \mathrm{min}$ at $265 \mathrm{~nm}$.

Results: The retention times of CF, BA, PP, BP, BHA and BHT were found about 3.6, 11.6, 13.0, 13.3, 13.6 and 16. 7 min, respectively. Results revealed that BA was found in $17.1 \%$ of the products within the concentration range of $11 \sim 2067 \mathrm{mg} / \mathrm{L}$; among these, $42.9 \%$ products exceeded the allowable limit of $300 \mathrm{mg} / \mathrm{L}$ set by JECFA. Moreover, $14.6 \%$ products showed positive response to $C F$ at a concentration of $10 \sim 18 \mathrm{mg} / \mathrm{L}$, which was well below the tolerance limit ( $<200 \mathrm{mg} / \mathrm{L}$ ) set by FDA. However, none of these investigated dairy products were found to contain any detectable amount of $\mathrm{PP}, \mathrm{BP}, \mathrm{BHA}$ or $\mathrm{BHT}$.
\end{abstract}

Conclusion: Presence of excess amount of BA in dairy products, which are one of the most favorite healthy food items for all generations, can easily jeopardize public health sector. Moreover, CF was found in some CF-free products, which is also an alarming issue to be considered seriously to prevent the future occurrence of it.

Keywords: Dairy products, HPLC, Caffeine, Preservatives, Antioxidants, Food security

\section{Background}

People, especially children, consume substantial amount (30 to $150 \mathrm{~kg} / \mathrm{capita} /$ year) of fresh milk and dairy products every day (FAO 2013a). Milk is a valuable nutritious food with a short shelf-life and requires careful handling as it is highly perishable being an excellent medium for the growth of microorganisms-particularly bacterial pathogens-that can cause spoilage and diseases amongst the consumers. Milk processing like mechanical refrigeration, pasteurization etc. allows the preservation of milk for days, weeks or even months and helps to reduce food-borne illness (FAO 2013b). Processing of dairy products gives

\footnotetext{
*Correspondence: rouf321@yahoo.com

Institutional address: Department of Pharmaceutical Technology, Faculty of Pharmacy, University of Dhaka, Dhaka 1000, Bangladesh
}

small-scale dairy producers higher cash incomes than selling raw milk, and offers better opportunities to reach regional and urban markets and helps to deal with seasonal fluctuations in milk supply. The transformation of raw milk into processed milk and products can benefit entire communities by generating off-farm jobs in milk collection, transportation, processing and marketing (FAO 2013b).

Bangladesh is nearly self-sufficient in food production, but unfortunately food security remains an elusive goal nowadays. Shortage of storage facilities, lack of academic education, frequent natural disasters, poverty, and lack of strict monitoring systems sometimes lead the crooked producers and businessmen not to apply the standard food processing procedures; rather frequently they add uncontrolled amount of different food preservatives and/ or antioxidants in the food products, thus make the 
product adulterated. It is hard to believe that the percentage of these sorts of debased food products are increasing at an alarming rate and consumed by the common people across the country. Therefore, food-borne illness, intoxication and malnutrition are the common scenario in Bangladesh-more severely in the underdeveloped rural areas (Ali 2013; Rahman and Kabir 2012; Hossain et al. 2008). Numerous reports on adulteration of foods and food products are often published in the mainstream national newspapers as well as broadcasted in the television or radio that also inspired us to do in-depth research in this field. Even the National Food Safety Laboratory (NFSL) of our country found the presence of two harmful and banned pesticides-Aldrin and DDT in their investigated raw milk and milk products in 2014 (NFSL 2014). Beside this, in 2012, Chanda et al. found that all fifty milk samples collected from Barisal district of Bangladesh were adulterated with water and more interestingly, $10 \%$ of those samples were adulterated with toxic formalin and $20 \%$ with sodium bicarbonate. These types of abominable activities are increasing day by day due to lack of government and public awareness, greediness of businessmen, lack of regulations and standards, and finally lack of implementation of existing laws (Rahman and Kabir 2012).

Usually coliforms, lactic acid bacteria, yeasts, and molds are responsible for the spoilage of milk, but psychrotrophic organisms play the most dominant role. In addition, various bacteria of public health concern such as Salmonella spp., Listeria monoytogenes, Camphylobacter jejuni, Yersinia enterocolitica, pathogenic strains of Eshcherichia coli and enterotoxigenic strains of Staphylococcus aureus may also be found in milk and dairy products (Cempírková and Mikulová 2009; Varga 2007). These microorganisms and their metabolic end products are greatly harmful for human body. So, suitable preservation techniques are to be applied to prevent microbial and chemical spoilage of dairy products. The most important means of controlling bacteria, yeasts and molds are application of heat, cold, chemicals, radiation etc. Usually food industries incorporate two or more preservation techniques to preserve their products (Potter and Hotchkiss 1999). Mechanical cooling, thermization, pasteurization and ultra-heat treatment are regularly applied to dairy products (Guizani 2007). However, according to WHO/FAO authorized "codex general standard for food additives" guideline published in 1995, our all investigated dairy products have no permission to apply chemical preservation technique using any preservatives and antioxidants, except flavored yogurt in which only benzoic acid (BA) (Fig. 1) can be used in a concentration of less than $300 \mathrm{mg} / \mathrm{L}$ (Codex 2015). There is no specific rule on the use of caffeine (CF) in dairy products (Nutri pro 2013), but it may be present in chocolate milk prepared with cocoa powder considering the fact that its concentration should be well below the maximum daily allowable level of it. Excess intake of CF causes headache, insomnia, agitation, tremor, hypertonicity, systemic hypokalemia, tinnitus, tachyarrhythmia, delirium, hyperventilation, hyperthermia, polyuria, dehydration, seizures, and coma (Simmons and Kidner 1998; Davies et al. 2012). On the other hand, BA may cause asthma, urticaria, metabolic acidosis, convulsions etc. if exceeds $5 \mathrm{mg} / \mathrm{kg}$ b.w. and it may also form benzene by reacting with ascorbic acid (usually present in yogurt) in the presence of transitionmetal catalyst (Qi et al. 2008; Roye et al. 2009). Decline in serum testosterone level in male persons and hypersensitivity reaction may occur if the intake amount of propylparaben (PP) and butylparaben (BP) exceed $10 \mathrm{mg} / \mathrm{kg}$ b.w. (WHO 2010; Roye et al. 2009). Moreover, butylated<smiles>Cn1c(=O)c2c(ncn2C)n(C)c1=O</smiles><smiles>CCCCOC(=O)c1ccc(O)cc1</smiles>

Butyl paraben<smiles>O=C(O)c1ccccc1</smiles>

Benzoic acid<smiles>COc1ccc(O)c(C(C)(C)C)c1</smiles>

Butyiated hydroxyanis ole<smiles>CCCOC(=O)c1ccc(O)cc1</smiles>

Propyl paraben<smiles>Cc1cc(C(C)(C)C)c(O)c(C(C)(C)C)c1</smiles>

Butylated hydroxytolvene

Fig. 1 Structural formula of the six additives 
Table 1 The types and sources of collected dairy products

\begin{tabular}{llll}
\hline Parameters & $\begin{array}{l}\text { Non-heat } \\
\text { treated }\end{array}$ & Heat treated & \\
\cline { 3 - 4 } & UHTa -processed & Pasteurized \\
\hline Products quantity & 16 & 16 & 9 \\
Source of origin & Local: 16 & Local: 12 & Local: 9 \\
& Imported: Nil $^{\text {b }}$ & Imported: 4 & Imported: Nil $^{\text {b }}$ \\
\hline
\end{tabular}

aHT stands for Ultra Heat Treatment

${ }^{\mathrm{b}} \mathrm{Nil}$ means zero product of that type

hydroxyanisole (BHA) may cause carcinogenic effect when the daily ingestion crosses the limit of $500 \mathrm{mcg} / \mathrm{kg}$ b.w. (Report on Carcinogens 2014), whereas severe nausea and vomiting may occur following the ingestion of butylated hydroxytoluene (BHT), whose ADI is $125 \mathrm{mcg} / \mathrm{kg}$ b.w. (Roye et al. 2009). So, it would be a better approach to collect milk by maintaining proper cleanliness and sanitation, and then applying cooling and/or thermization technique (Guizani 2007).

CF can be quantitatively analyzed using gas chromatography-mass spectrometry (Kerrigan and Lindsey 2005; Ayala et al. 2009), HPLC (Sather and Vernig 2011; Srdjenovic et al. 2008), surfactant-mediated matrixassisted laser desorption/ionization time-of-flight mass spectrometry (Grant and Helleur 2008), micellar electrokinetic capillary chromatography (Injac 2008), ultraviolet visible absorption spectrometry and thin layer chromatography (Sather and Vernig 2011). The determination of BA and parabens can be carried out by HPLC (Saad et al. 2005; Mroueh et al. 2008; Petronela and Elena 2009; Khosrokhavar et al. 2010; Tawalbeh et al. 2014), capillary electrophoresis (Tang and Wu 2007). The analysis of BHA and BHT can be done with liquid chromatography-mass spectrometry (Lee et al. 2006), nonisothermal pressurized-differential scanning calorimetry (Dunn 2005), gas chromatography (Yang et al. 2002), and square-wave voltammetry (Medeiros et al. 2010).

Studying inquisitively and applying many of these practically, a suitable and precise RP-HPLC method was developed for the simultaneous determination of $\mathrm{CF}$, BA, PP, BP, BHA and BHT. As a part of our continuous interest in the researches of adulteration studies on food, soft drinks, cosmetics and dairy products, we herein report a validated method and the result of our study to explore the presence or absence of CF, BA, PP, BP, BHA and BHT in dairy products, and their compliance with

Table 2 Composition of mobile phase of the RP-HPLC method

\begin{tabular}{lll}
\hline Time $(\mathrm{min})$ & Diluted sulfuric acid $(0.002 \mathrm{M})(\%)$ & Acetonitrile (\%) \\
\hline $0.01-10.00$ & 85 & 15 \\
$10.01-11.00$ & 40 & 60 \\
$11.01-13.00$ & 30 & 70 \\
$13.01-16.00$ & 20 & 80 \\
$16.01-18.00$ & 85 & 15 \\
\hline
\end{tabular}

Table 3 System suitability of the proposed method

\begin{tabular}{lccc}
\hline Standards & \multicolumn{1}{c}{$\begin{array}{l}\text { Peak area } \\
(\text { Mean } \pm \% R S D)^{a}\end{array}$} & $\begin{array}{l}\text { Retention time } \\
(\text { Mean } \pm \% R S D)^{a}\end{array}$ & $\begin{array}{l}\text { Tailing factor } \\
(\text { Mean } \pm \% R S D)^{a}\end{array}$ \\
\hline CF & $1865839 \pm 0.71$ & $3.6 \pm 0.04$ & $0.866 \pm 0.44$ \\
BA & $986908 \pm 0.50$ & $11.6 \pm 0.05$ & $1.075 \pm 0.37$ \\
PP & $994208 \pm 0.35$ & $13.0 \pm 0.02$ & $1.248 \pm 0.33$ \\
BP & $858343 \pm 0.43$ & $13.3 \pm 0.04$ & $1.229 \pm 0.20$ \\
BHA & $234037 \pm 0.94$ & $13.6 \pm 0.03$ & $1.224 \pm 0.22$ \\
BHT & $177374 \pm 0.59$ & $16.7 \pm 0.03$ & $1.017 \pm 0.49$ \\
\hline
\end{tabular}

$C F$ caffeine, $B A$ benzoic acid, $P P$ propylparaben, $B P$ butylparaben, $B H A$ butylated hydroxyanisole, $B H T$ butylated hydroxytoluene

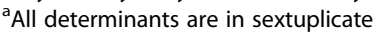

the existing rules and regulations listed by the regulatory bodies. To the best of our knowledge, this is the first study for the assay of such additives in dairy products available in Bangladesh.

\section{Methods}

\section{Chemicals and reagents}

All six working standards of CF, BA, PP, BP, BHA and BHT were gifted by Eskayef Bangladesh Limited, Gazipur, Bangladesh. HPLC grade sulfuric acid (Sigma Aldrich, Germany), HPLC grade acetonitrile (RCI Labscan, Thailand) and analytical grade trichloroacetic acid (BDH Chemicals, England) were used for analytical purposes. Milli-Q water was used to prepare the mobile phase.

\section{Sample collection and storage}

Forty one marketed dairy products were collected from departmental stores, supermarkets and dairy farms in Dhaka, Bangladesh during mid-2013. Among them, 37 products were local and 4 products were imported. There were 10 full cream milk, 7 locally collected milk (bought from local dairy farms), 6 chocolate milk, 5 mango milk, 8 buttermilk, 2 skimmed milk, 1 banana milk, 1 flavored yogurt and 1 lassi i.e. a sweet or savory Indian drink made from yogurt or buttermilk base with water. The different types of collected dairy products are listed in Table 1. In the product label claim it was observed that only two pasteurized chocolate milk and four UHT-processed

Table 4 Linearity study of the proposed method

\begin{tabular}{lllc}
\hline Standards & $\begin{array}{l}\text { Concentration } \\
\text { range }(\mathrm{mg} / \mathrm{L})\end{array}$ & $\begin{array}{l}\text { Regression equation } \\
(\mathrm{Y}=\mathrm{mX}+\mathrm{c})\end{array}$ & $\begin{array}{c}\text { Correlation } \\
\text { coefficient }\left(\mathrm{R}^{2}\right)\end{array}$ \\
\hline CF & $2-200$ & $\mathrm{Y}=23019 \mathrm{X}-42400$ & 0.996 \\
BA & $50-500$ & $\mathrm{Y}=14211 \mathrm{X}-43609$ & 0.992 \\
PP & $2-100$ & $\mathrm{Y}=10605 \mathrm{X}-11766$ & 0.992 \\
BP & $2-100$ & $\mathrm{Y}=9294 \mathrm{X}-84770$ & 0.997 \\
BHA & $50-300$ & $\mathrm{Y}=1720 \mathrm{X}+10364$ & 0.996 \\
BHT & $50-300$ & $\mathrm{Y}=1855 \mathrm{X}-46598$ & 0.998 \\
\hline
\end{tabular}

$C F$ caffeine, $B A$ benzoic acid, $P P$ propylparaben, $B P$ butylparaben, $B H A$ butylated hydroxyanisole, $B H T$ butylated hydroxytoluene 
Table 5 LOD and LOQ of the standards in the proposed method

\begin{tabular}{lcc}
\hline Standards & LOD $(\mu \mathrm{g} / \mathrm{L})$ & LOQ $(\mu \mathrm{g} / \mathrm{L})$ \\
\hline CF & 2.66 & 8.06 \\
BA & 2.70 & 8.18 \\
PP & 0.21 & 0.64 \\
BP & 0.20 & 0.60 \\
BHA & 2.13 & 6.45 \\
BHT & 1.42 & 4.30 \\
\hline
\end{tabular}

$C F$ caffeine, $B A$ benzoic acid, $P P$ propylparaben, $B P$ butylparaben, $B H A$ butylated hydroxyanisole, $B H T$ butylated hydroxytoluene

Table 6 Results of accuracy determination

\begin{tabular}{|c|c|c|c|}
\hline Standards & $\begin{array}{l}\text { Amount used (mg/L) } \\
\text { eq. to }(80 \%-120 \%) \\
\text { respectively }\end{array}$ & $\begin{array}{l}\text { Amount recovered } \\
(\mathrm{mg} / \mathrm{L})\end{array}$ & $\begin{array}{l}\text { \% Recovery } \\
(\text { Mean } \pm \% \text { RSD) }\end{array}$ \\
\hline \multirow[t]{5}{*}{$\overline{C F}$} & 60 & 59.66 & $99.44 \pm 0.025$ \\
\hline & 67.5 & 67.36 & $99.79 \pm 0.04$ \\
\hline & 75 & 74.62 & $99.48 \pm 0.045$ \\
\hline & 82.5 & 82.23 & $99.56 \pm 0.047$ \\
\hline & 90 & 89.69 & $99.64 \pm 0.02$ \\
\hline \multirow[t]{5}{*}{ BA } & 200 & 198.59 & $99.30 \pm 0.04$ \\
\hline & 225 & 223.65 & $99.41 \pm 0.03$ \\
\hline & 250 & 247.62 & $99.05 \pm 0.02$ \\
\hline & 275 & 273.22 & $99.33 \pm 0.02$ \\
\hline & 300 & 297.61 & $99.20 \pm 0.02$ \\
\hline \multirow[t]{5}{*}{ PP } & 20 & 19.23 & $96.03 \pm 0.4$ \\
\hline & 22.5 & 22.03 & $97.92 \pm 0.25$ \\
\hline & 25 & 24.23 & $96.77 \pm 0.14$ \\
\hline & 27.5 & 27.08 & $98.4 \pm 0.22$ \\
\hline & 30 & 29.25 & $97.33 \pm 0.21$ \\
\hline \multirow[t]{5}{*}{$\mathrm{BP}$} & 20 & 19.27 & $96.18 \pm 0.16$ \\
\hline & 22.5 & 21.99 & $97.78 \pm 0.12$ \\
\hline & 25 & 24.28 & $96.96 \pm 0.19$ \\
\hline & 27.5 & 27.03 & $98.28 \pm 0.2$ \\
\hline & 30 & 29.26 & $97.31 \pm 0.22$ \\
\hline \multirow[t]{5}{*}{$\mathrm{BHA}$} & 160 & 158.31 & $98.9 \pm 0.045$ \\
\hline & 180 & 178.33 & $99.06 \pm 0.036$ \\
\hline & 200 & 197.58 & $98.77 \pm 0.087$ \\
\hline & 220 & 218.42 & $99.25 \pm 0.06$ \\
\hline & 240 & 238.42 & $99.34 \pm 0.015$ \\
\hline \multirow[t]{5}{*}{$\mathrm{BHT}$} & 160 & 158.72 & $99.16 \pm 0.04$ \\
\hline & 180 & 178.22 & $99.0 \pm 0.04$ \\
\hline & 200 & 198.75 & $99.34 \pm 0.09$ \\
\hline & 220 & 218.22 & $99.17 \pm 0.025$ \\
\hline & 240 & 238.10 & $99.2 \pm 0.02$ \\
\hline
\end{tabular}

$C F$ caffeine, $B A$ benzoic acid, $P P$ propylparaben, $B P$ butylparaben, $B H A$ butylated hydroxyanisole, $B H T$ butylated hydroxytoluene

${ }^{a}$ All determinants are in triplicate chocolate milk products declared the presence of cocoa powder, which is a common source of CF but most of the manufacturers did not claim about the presence of BA, PP, $\mathrm{BP}, \mathrm{BHA}$ and BHT. These samples were stored in a refrigerator below $4{ }^{\circ} \mathrm{C}$ till further use.

\section{Equipment}

Kubota-2100 centrifuge machine (Kubota, Japan) and Cyberscan $500 \mathrm{pH}$ meter (Eutech, Singapore) were used to prepare the samples. Cole-Parmer Filtration machine (USA) was used to filter the mobile phase. To analyze samples a binary HPLC system (Shimadzu, Japan) equipped with a vacuum degasser (Model: DGU-20A3) and a UV/Vis detector (Model: SPD-20A) was used.

\section{Chromatographic conditions}

The separation was achieved using a $5 \mu \mathrm{m}$ particle sized Capcell Pak octadecylsilyl (ODS) column (150 $\mathrm{mm} \times$ $4.6 \mathrm{~mm}$ i.d.) (Shiseido, Japan) with the mobile phase consisting of acetonitrile and diluted sulfuric acid $(0.002 \mathrm{M})$ at a binary gradient as shown in Table 2 . The mobile phase flow rate was $2.0 \mathrm{~mL} / \mathrm{min}$ and the injection volume was $20 \mu \mathrm{L}$. The column oven temperature was set at $30^{\circ} \mathrm{C}$ and the analysis was performed at $265 \mathrm{~nm}$ wavelength.

\section{Preparation of solutions \\ Preparation of standard solution}

A standard solution was prepared by adding working standards of CF (75 mg/L), BA (250 mg/L), PP ( $25 \mathrm{mg} / \mathrm{L})$, BP $(25 \mathrm{mg} / \mathrm{L})$, BHA $(200 \mathrm{mg} / \mathrm{L})$ and BHT $(200 \mathrm{mg} / \mathrm{L})$ and was used to analyze the investigated sample preparations.

\section{Preparation of sample solution}

Accurately measured $40 \mathrm{~mL}$ of marketed product was taken into a centrifuge tube with $4 \mathrm{~mL}$ of trichloroacetic acid, used to precipitate fat and protein present in milk and milk products and then it was centrifuged for $10 \mathrm{~min}$ at $3000 \mathrm{rpm}$. The supernatant was then filtered using a Whatmann 41 filter paper to obtain the final

Table 7 Precision of the proposed method

\begin{tabular}{llrr}
\hline Standards & Spike level $^{\mathrm{a}}(\%)$ & $\begin{array}{l}\text { Intra-day } \\
(\text { Mean } \pm \% R S D)\end{array}$ & \multicolumn{1}{l}{$\begin{array}{l}\text { Inter-day } \\
(\text { Mean } \pm \% R S D)\end{array}$} \\
\hline CF & 100 & $1865839 \pm 0.71$ & $1855736 \pm 0.63$ \\
BA & 100 & $986908 \pm 0.50$ & $982929 \pm 0.56$ \\
PP & 100 & $994208 \pm 0.35$ & $985310 \pm 0.46$ \\
BP & 100 & $858343 \pm 0.43$ & $852766 \pm 0.76$ \\
BHA & 100 & $216226 \pm 0.80$ & $213500 \pm 0.86$ \\
BHT & 100 & $234037 \pm 0.94$ & $214671 \pm 0.69$
\end{tabular}

$C F$ caffeine, $B A$ benzoic acid, $P P$ propylparaben, $B P$ butylparaben, $B H A$ butylated hydroxyanisole, $B H T$ butylated hydroxytoluene

${ }^{a}$ Spike level indicates the corresponding nominal concentration of each standard

${ }^{\mathrm{b}}$ All determinants are in sextuplicate 
Table 8 Ruggedness study of the proposed method

\begin{tabular}{|c|c|c|c|c|}
\hline \multirow[t]{2}{*}{ Standards } & \multicolumn{2}{|l|}{ Analyst 1} & \multicolumn{2}{|l|}{ Analyst 2} \\
\hline & Amount found $(\mathrm{mg} / \mathrm{L})$ & $\%$ Recovery (Mean $\pm \%$ RSD) & Amount found (mg/L) & $\%$ Recovery (Mean $\pm \%$ RSD) \\
\hline CF & 74.61 & $99.48 \pm 0.045$ & 74.67 & $99.51 \pm 0.05$ \\
\hline BA & 247.62 & $99.05 \pm 0.02$ & 247.57 & $99.03 \pm 0.06$ \\
\hline PP & 24.19 & $96.77 \pm 0.41$ & 24.21 & $96.81 \pm 0.54$ \\
\hline $\mathrm{BP}$ & 24.23 & $96.96 \pm 0.19$ & 24.16 & $96.15 \pm 0.63$ \\
\hline $\mathrm{BHA}$ & 197.76 & $98.77 \pm 0.09$ & 197.56 & $98.13 \pm 0.07$ \\
\hline BHT & 198.16 & $98.88 \pm 0.03$ & 197.99 & $98.12 \pm 0.09$ \\
\hline
\end{tabular}

CF caffeine, $B A$ benzoic acid, $P P$ propylparaben, $B P$ butylparaben, $B H A$ butylated hydroxyanisole, $B H T$ butylated hydroxytoluene

${ }^{a}$ All determinants are in sextuplicate

sample (King 1962). And the blank consisted of acetonitrile, diluted sulfuric acid $(0.002 \mathrm{M})$ and trichloroacetic acid.

\section{Validation of the test procedure}

Method validation study was performed based on the current pharmaceutical regulatory guidelines i.e., ICH Q2 (R1). A number of parameters such as precision, accuracy, specificity, linearity, ruggedness and robustness were investigated for this purpose.

\section{System suitability}

For the evaluation of system suitability, the repeatability, retention time and tailing factor of six replicates of working standards of CF $(75 \mathrm{mg} / \mathrm{L})$, BA $(250 \mathrm{mg} / \mathrm{L})$, PP $(25 \mathrm{mg} / \mathrm{L})$, BP $(25 \mathrm{mg} / \mathrm{L})$, BHA $(200 \mathrm{mg} / \mathrm{L})$ and BHT $(200 \mathrm{mg} / \mathrm{L})$ were used and percentage relative standard deviation (\%RSD) values were calculated in each case.

\section{Linearity}

The linearity was checked by analyzing different concentrations of CF $(2-200 \mathrm{mg} / \mathrm{L}), \mathrm{BA}(50-500 \mathrm{mg} / \mathrm{L})$, PP (2$100 \mathrm{mg} / \mathrm{L})$, BP $(2-100 \mathrm{mg} / \mathrm{L})$, BHA $(50-300 \mathrm{mg} / \mathrm{L})$ and BHT (50-300 mg/L). Calibration curves were made using MS Excel 2007 for each standard component. The regression line was calculated as $\mathrm{Y}=\mathrm{mX}+\mathrm{c}$, where $\mathrm{X}$ was the concentration of standard and $\mathrm{Y}$ was the response (peak area expressed as AU).

Limits of detection (LOD) and Limits of quantitation (LOQ) LOD and LOQ were calculated according to ICH Q2 (R1) recommendations in accordance with the $3.3 \mathrm{~s} / \mathrm{m}$ and $10 \mathrm{~s} / \mathrm{m}$ criteria respectively, where ' $\mathrm{s}$ ' is the standard deviation of the peak area and ' $m$ ' is the slope of the calibration curve determined from linearity investigation.

\section{Accuracy (Recovery Test)}

Recovery test was done by analyzing a sample of known concentration of standard solutions. Then percent recoveries (mean \pm \%SD of three replicates) were calculated.

\section{Precision}

Repeatability (intra-day precision) and intermediate precision (inter-day precision) of the method were determined by using the solution of standards i.e. CF $(75 \mathrm{mg} /$ $\mathrm{L}), \mathrm{BA}(250 \mathrm{mg} / \mathrm{L})$, PP $(25 \mathrm{mg} / \mathrm{L})$, BP $(25 \mathrm{mg} / \mathrm{L})$, BHA $(200 \mathrm{mg} / \mathrm{L})$ and BHT $(200 \mathrm{mg} / \mathrm{L})$ and the solutions were analyzed in six replicates in the same day (intra-day precision) and daily for six times over a period of three days (inter-day precision).

Table 9 Robustness study of the proposed method

\begin{tabular}{|c|c|c|c|c|c|c|c|}
\hline \multirow[t]{3}{*}{ Standards } & \multirow{3}{*}{$\begin{array}{l}\text { Standards } \\
(\mathrm{mg} / \mathrm{L})\end{array}$} & \multicolumn{6}{|c|}{ Amount detected $(\mathrm{mg} / \mathrm{L})(\text { mean } \pm \% \mathrm{RSD})^{\mathrm{a}}$} \\
\hline & & \multicolumn{3}{|c|}{ Change in flow rate } & \multicolumn{3}{|l|}{ Change in $\mathrm{pH}$} \\
\hline & & $1.9 \mathrm{~mL} / \mathrm{min}$ & $2.0 \mathrm{~mL} / \mathrm{min}$ & $2.1 \mathrm{~mL} / \mathrm{min}$ & 2.2 & 2.3 & 2.4 \\
\hline CF & 75 & $74.69 \pm 0.08$ & $74.62 \pm 0.05$ & $74.59 \pm 0.02$ & $74.63 \pm 0.02$ & $74.62 \pm 0.05$ & $74.63 \pm 0.04$ \\
\hline BA & 250 & $247.64 \pm 0.01$ & $247.61 \pm 0.02$ & $247.55 \pm 0.01$ & $247.68 \pm 0.01$ & $247.61 \pm 0.02$ & $247.59 \pm 0.01$ \\
\hline PP & 25 & $24.24 \pm 0.04$ & $24.23 \pm 0.04$ & $24.18 \pm 0.04$ & $24.23 \pm 0.04$ & $24.23 \pm 0.04$ & $24.23 \pm 0.04$ \\
\hline $\mathrm{BP}$ & 25 & $24.25 \pm 0.06$ & $24.28 \pm 0.04$ & $24.23 \pm 0.09$ & $24.27 \pm 0.06$ & $24.28 \pm 0.04$ & $24.25 \pm 0.10$ \\
\hline $\mathrm{BHA}$ & 200 & $197.61 \pm 0.01$ & $197.58 \pm 0.02$ & $197.52 \pm 0.01$ & $197.58 \pm 0.01$ & $197.58 \pm 0.02$ & $197.58 \pm 0.02$ \\
\hline BHT & 200 & $198.7 \pm 0.01$ & $198.75 \pm 0.03$ & $198.67 \pm 0.01$ & $198.71 \pm 0.01$ & $198.75 \pm 0.03$ & $198.75 \pm 0.02$ \\
\hline
\end{tabular}

CF caffeine, $B A$ benzoic acid, $P P$ propylparaben, $B P$ butylparaben, $B H A$ butylated hydroxyanisole, $B H T$ butylated hydroxytoluene

${ }^{a}$ All determinants are in triplicate 


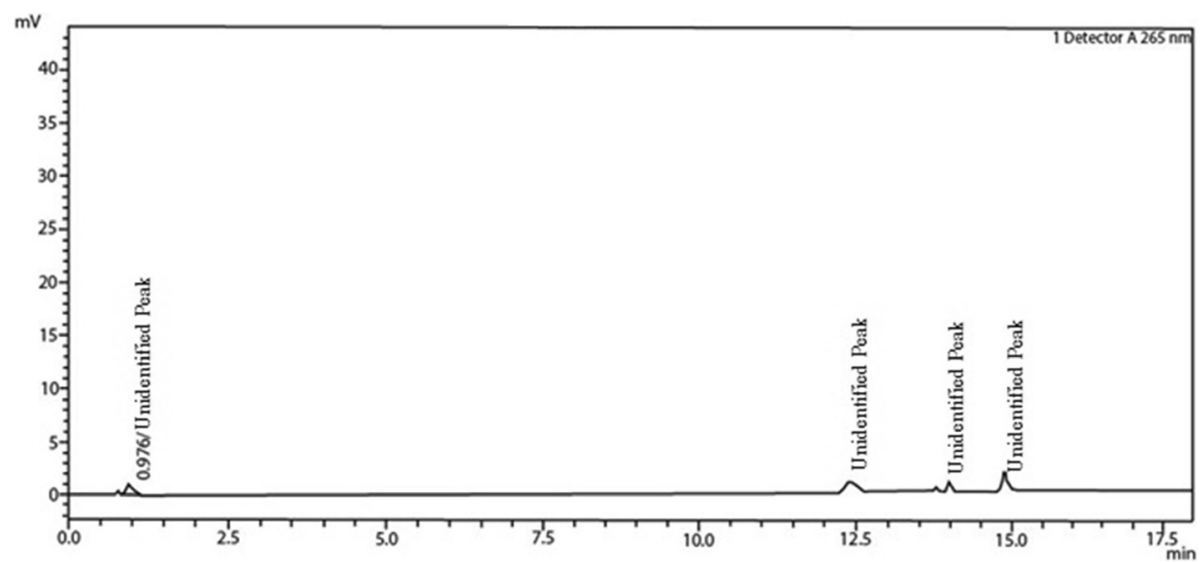

Fig. 2 HPLC chromatogram of blank

\section{Ruggedness}

Ruggedness of the method was determined by analyzing six assay sample solutions of standard CF (75 mg/L), BA (250 mg/L), PP (25 mg/L), BP (25 mg/L), BHA (200 mg/L) and BHT $(200 \mathrm{mg} / \mathrm{L})$ by two analysts in the same laboratory to check the reproducibility of the result. The percentage recovery and \%RSD were calculated in both cases.

\section{Robustness}

To determine the robustness of the method, flow rate of the mobile phase and the $\mathrm{pH}$ of the diluted sulfuric acid were slightly changed. The \%RSD of robustness testing under these conditions was calculated in all cases.

\section{Results and discussion Method validation System suitability}

The results (Mean $\pm \%$ RSD of six replicates of the standards) of the chromatographic parameters are shown in Table 3, which indicate the good performance of the system.

\section{Linearity}

The relevant information is shown on Table 4 . The correlation coefficient values of all six investigated ingredients are shown well within (0.99-1.00), which indicate the linearity of the proposed method.

Limits of detection (LOD) and Limits of quantitation (LOQ) The LOD and LOQ values of CF, BA, PP, BP, BHA and BHT are shown in Table 5, indicating that the proposed method is well sensitive.

\section{Accuracy (Recovery Test)}

The overall recoveries of the standards are summarized in Table 6. Almost all results showed very good recoveries at five different concentration levels.

\section{Precision}

The results obtained are presented in Table 7. Intra-and inter-day results were found very close to those of the

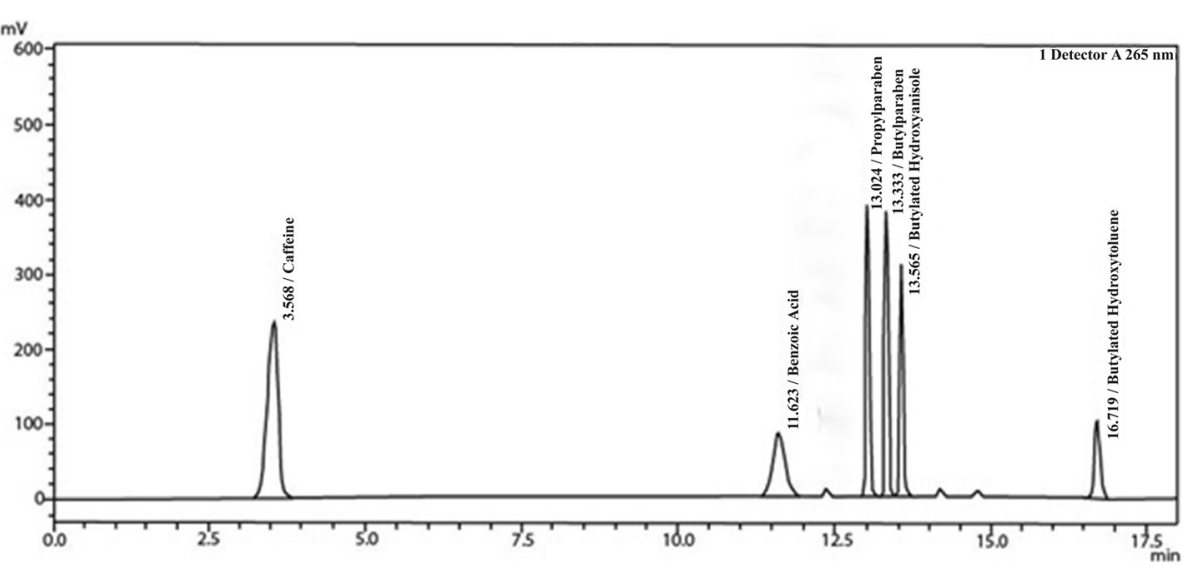

Fig. 3 HPLC chromatogram of standards 


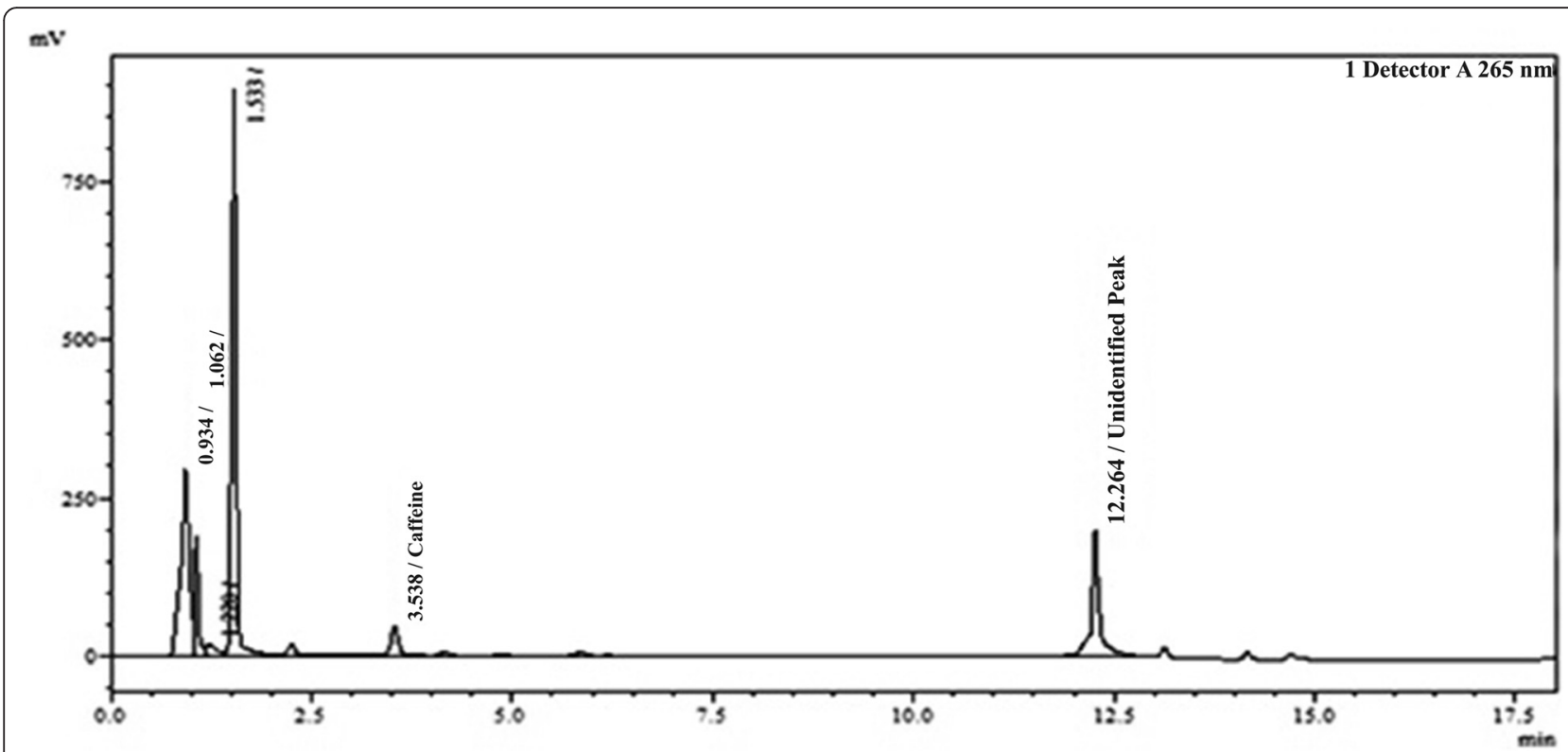

Fig. 4 HPLC chromatogram of a sample showing positive response to caffeine (CF)

corresponding freshly prepared nominal concentration, but inter-day results are slightly more deviated from the norms.

\section{Ruggedness}

The results (mean of \%recovery $\pm \%$ RSD of six assay samples) of the ruggedness test are presented in Table 8.

\section{Robustness}

The $\mathrm{pH}$ of the $0.002 \mathrm{M}$ diluted sulfuric acid was reproducibly found about 2.3. The robustness of the method has been checked changing the $\mathrm{pH}$ of diluted sulfuric acid as well as flow rate of mobile phase. The results (mean $\pm \%$ RSD of three assay samples) of the robustness study are given in Table 9.

Quantitation of CF, BA, PP, BP, BHA and BHT in the dairy products

A precise, robust and rugged RP-HPLC method for simultaneous analysis of CF, BA, PP, BP, BHA and BHT was developed to investigate 41 marketed dairy products within a shortest possible time. Our designed analytical

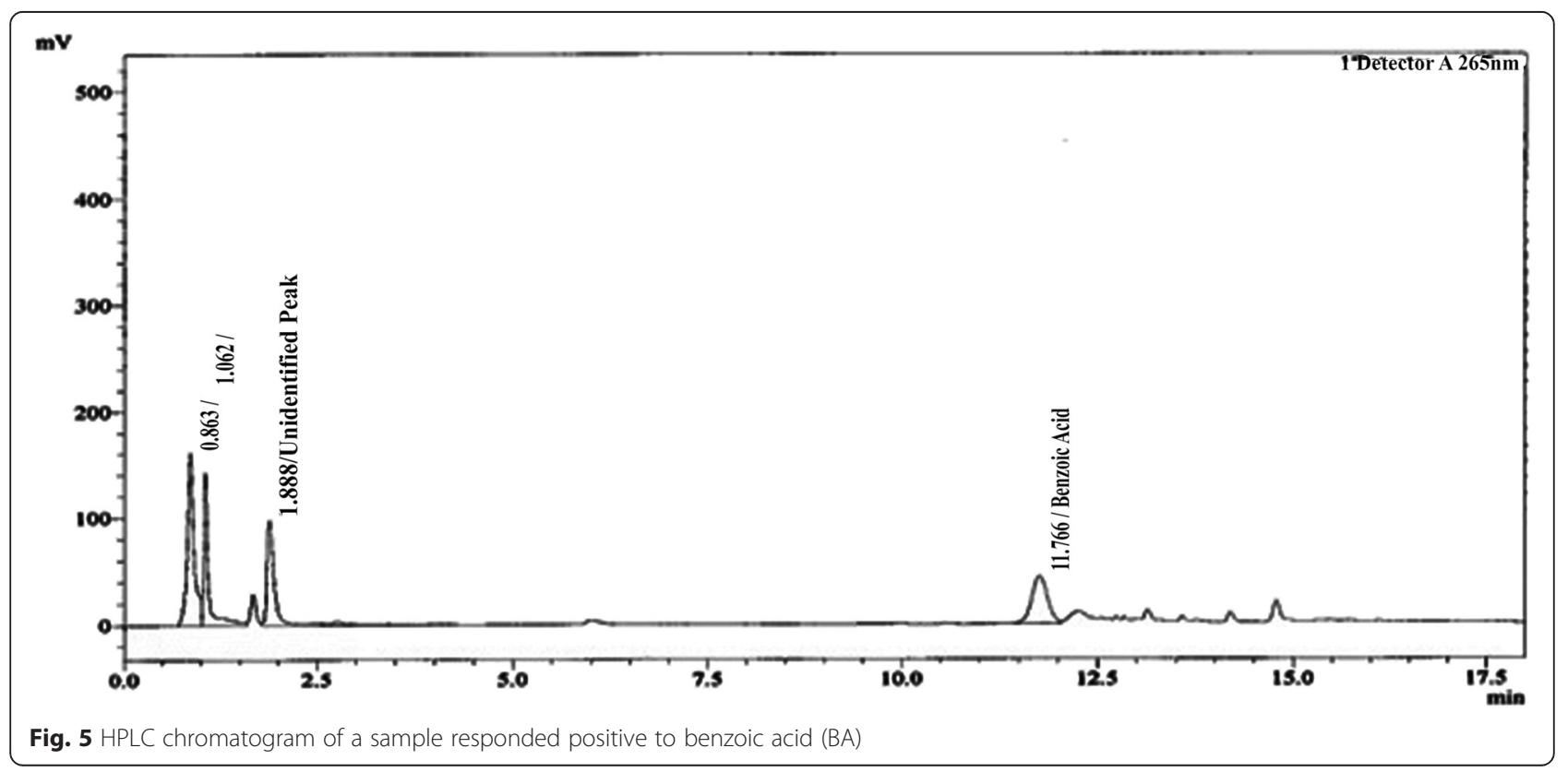


Table 10 The concentrations of CF and BA in dairy products

\begin{tabular}{|c|c|c|c|}
\hline \multicolumn{2}{|l|}{ Estimation of CF } & \multicolumn{2}{|l|}{ Estimation of BA } \\
\hline $\begin{array}{l}\text { CF positive dairy } \\
\text { products }\end{array}$ & Concentration of caffeine present $(\mathrm{mg} / \mathrm{L})(\text { mean } \pm \% R S D)^{a}$ & BA positive dairy products & $\begin{array}{l}\text { Concentration of BA present } \\
(\mathrm{mg} / \mathrm{L})(\text { mean } \pm \% R S D)^{\mathrm{a}}\end{array}$ \\
\hline $\mathrm{C} 1$ & $12.28 \pm 0.66$ & M1 & $65.22 \pm 0.09$ \\
\hline C2 & $14.4 \pm 0.40$ & M5 & $42.28 \pm 0.16$ \\
\hline C3 & $17.76 \pm 0.34$ & B1 & $55.30 \pm 0.12$ \\
\hline C4 & $10.93 \pm 0.33$ & $\mathrm{Y} 1$ & $11.68 \pm 0.39$ \\
\hline C5 & $13.57 \pm 0.28$ & G1 & $1875.65 \pm 0.15$ \\
\hline C6 & $14.79 \pm 0.26$ & G2 & $1074.85 \pm 0.16$ \\
\hline- & - & P1 & $2066.39 \pm 0.15$ \\
\hline
\end{tabular}

CF caffeine, $B A$ benzoic acid, $P$ P propylparaben, $B P$ butylparaben, $B H A$ butylated hydroxyanisole, $B H T$ butylated hydroxytoluene

${ }^{\text {a }}$ All determinants are in triplicate

method revealed their retention times of about 3.56 , $11.62,13.02,13.33,13.56$ and $16.72 \mathrm{~min}$, respectively, which is so far the best approach to analyze such a large number of dairy products. Figs. 2, 3, 4 and 5 represent the chromatograms of blank, six standards, a CF-positive product and a BA-positive product sequentially. Among the 41 dairy products, none was labeled to contain CF; rather 6 chocolate milks (composed of $14.6 \%$ of milk products) were labeled to contain cocoa powder instead. Only these 6 products showed positive response towards CF in the concentration range of $10 \sim 18 \mathrm{mg} / \mathrm{L}$. This range is well below the maximum allowable limit of CF, which is $200 \mathrm{mg} / \mathrm{L}$. The resultant concentrations of CF in these 6 milk products are individually presented in Table 10 .

Dairy products are available in Bangladesh as pasteurized form, UHT form and some are not heat treated. Two products out of 9 pasteurized dairy products and 4 products out of 16 UHT treated products contained CF and all of 16 not heat treated products did not contain CF. Independent of this type of treatment, every chocolate milk products whether they are heat treated or not as well as pasteurized or UHT treated were found CF positive. So, our study could not establish any relationship between heat treatment of the milk and the presence of CF. The presence of CF in pasteurized, UHT treated and not heat treated products are shown in Fig. 6.
There were 37 domestic milk and milk products and 4 products were imported from Australia, New Zealand, Ukraine and South Africa. Six out of 37 domestic dairy products were found to contain CF. The imported dairy products did not contain CF. Moreover, none of the imported products was chocolate milk products. There is no imported chocolate milk product available in Bangladesh. So, caffeine content could not be correlated with the products' origin i.e. whether they are imported or domestic. Interestingly, the presence of $\mathrm{CF}$ in the chocolate milks observed in this study is similar to the average content of $11 \mathrm{mg} / \mathrm{Kg}$ collected by Craig and Nguyen (1984). However, though the CF content found is low, the CF present in milk products may contribute to the exceeding of tolerance limit along with other $\mathrm{CF}$ rich products like tea, coffee, energy drinks etc.

Again, 7 out of 41 analyzed dairy products were found BA positive. The concentration of BA in these products was between $11 \sim 2067 \mathrm{mg} / \mathrm{L}$. Among these products, 2 were mango milk, 1each from banana milk, flavored yogurt, lassi, and 2 from buttermilk. The comparison is shown in Fig. 7. Beside this, all the pasteurized milk and milk products were BA negative, 5 among 16 UHT milk and milk products were found to contain BA whereas 2 out of 16 not heat-treated products showed positive response to BA which is shown in Fig. 8. Seven dairy

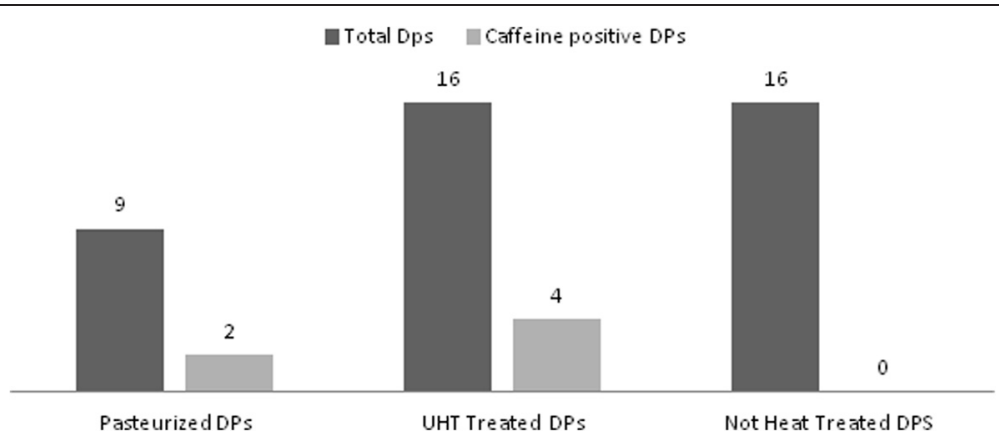

Fig. 6 Comparison of presence of caffeine (CF) in pasteurized, UHT treated dairy products (DPS) 


\section{Total CPS Benzoic Acid Positive DPS}

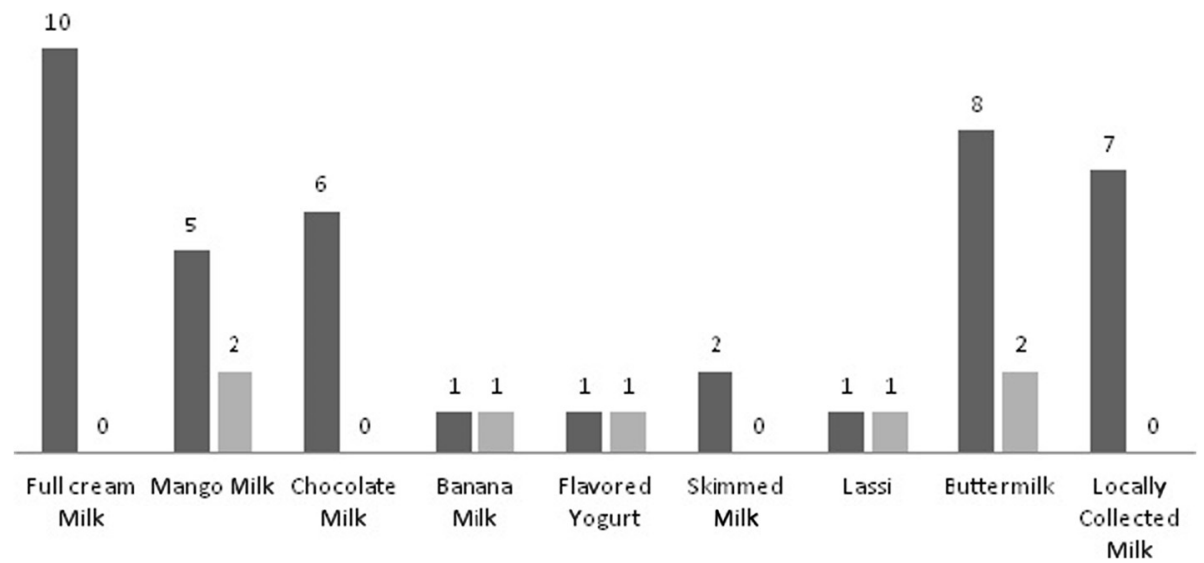

Fig. 7 Comparison of presence of benzoic acid (BA) in different types of dairy products (DPs)

products among 37 Bangladeshi milk products were found to contain BA. None of the imported milk products was found to contain BA.

According to the Joint FAO/WHO Expert Committee on Food Additives (JECFA), BA is only permitted to use in flavored yogurt up to the maximum use level of $300 \mathrm{mg} / \mathrm{L}$. Among 7 BA positive dairy products, only 1 product was flavored yogurt. Therefore, BA was approved to be used in only 1 product and the concentration of this product was about $11.68 \mathrm{mg} / \mathrm{L}$, which was well below the maximum use level set by JECFA. Six other BA positive products are not permitted to use BA. Moreover, 3 of them crossed the maximum permitted level of $300 \mathrm{mg} / \mathrm{L}$, even though BA is not permitted to be used in these products. Apart from these 3 products, 4 other BA positive products contained relatively very low amount of the additive which may be originated due to feeding practices, contamination, storage condition, and veterinary drugs. It is also well known that hippuric acid, a natural component of milk, may be converted to benzoic acid by the fermentation of lactic acid bacteria.
Further study needs to be carried out to confirm these sources.

However, the mean concentrations of benzoic acid observed by Qi et al. (2008) in pasteurized and UHT milk products in China were $3.6 \pm 3.3$ and $2.4 \pm 2.2 \mathrm{mg} / \mathrm{kg}$, ranging between $0.51-8.8$ and $0.62-13 \mathrm{mg} / \mathrm{Kg}$, respectively, where, the UHT milk products was plain milk. In our study, none of the analyzed pasteurized and nonflavored UHT milk products was found BA positive. Beside this, in Jordan, Mihyar et al. (1998) found BA in labaneh (concentrated yogurt) ranging from not detected to $2000 \mathrm{mg} / \mathrm{Kg}$, whereas, Tfouni and Toledo (2002) did not find BA in yogurt in Brazil while our study detected $\mathrm{BA}$ in the flavored yogurt. The concentration of BA found in the product was well below the maximum use level.

But, every analyzed milk products showed negative response to PP, BP, BHA and BHT. However, Pattono et al. (2009) revealed the presence of BHT in conventional milk and organic milk ranging from not detected to $1.45 \mathrm{mg} / \mathrm{L}$ and not detected to $1.67 \mathrm{mg} / \mathrm{L}$, respectively, in Italy,

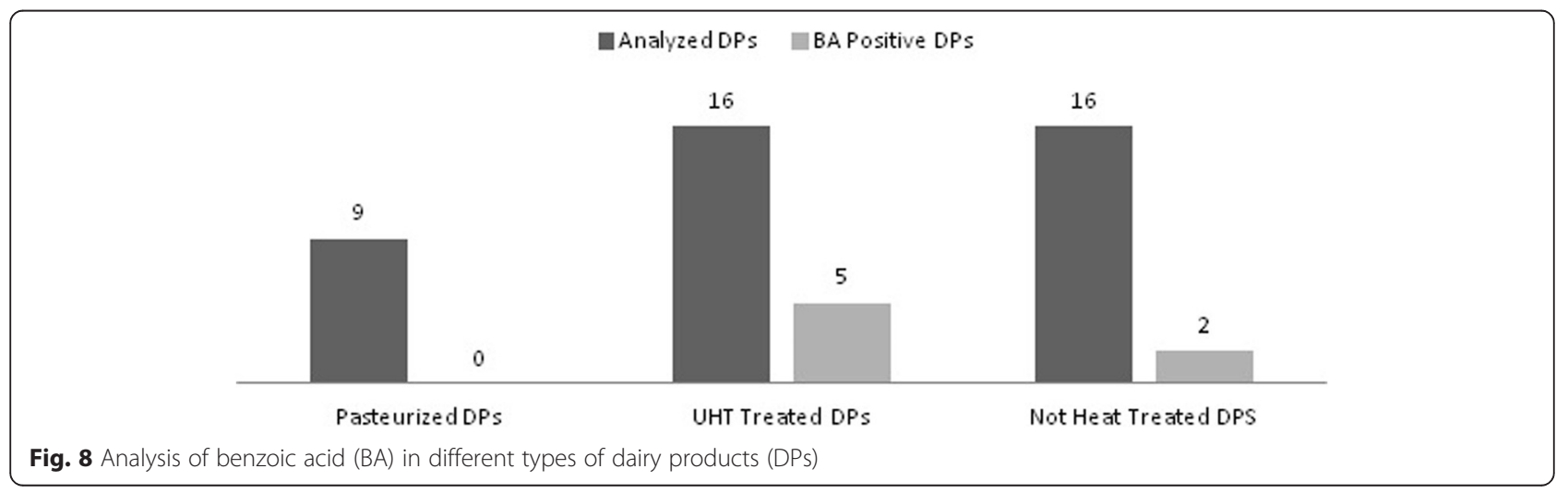


though, they did not find BHA in their samples. Though these 4 additives were not found within detectable range in our samples, continuous monitoring is necessary to maintain the situation.

Finally, since this is the first report from Bangladesh about using these six additives in dairy products, more studies should be carried out on a regular basis by researchers and respective regulatory bodies to protect common people from the uncontrolled consumption of these potentially harmful additives with highly nutritious dairy products.

\section{Conclusion}

The aim of this study was to explore the six additives in dairy products available in Bangladesh by developing a simple RP-HPLC method. The proposed time-programmed method can do it within $20 \mathrm{~min}$, including reequilibration. Our screening revealed the presence of $\mathrm{CF}$ and BA in several dairy products. The non-permitted use of BA in dairy products and the presence of $\mathrm{CF}$ in $\mathrm{CF}$-free products can be injurious to human health. So, we expect that the respective policy makers of Bangladesh will consider this outcome seriously and devise rules on them as quickly as possible.

\section{Abbreviations}

ADI, Acceptable Daily Intake; b.w., Body-weight; BA, Benzoic Acid; BHA Butylated hydroxyanisole; BHT, Butylated hydroxytoluene; BP, Butylparaben; CF, Caffeine; FDA, Food and Drug Administration; JECFA, Joint FAO/WHO Expert Committee on Food Additives; PP, Propylparaben; RP-HPLC, Reversed Phase High Performance Liquid Chromatography; WHO, World Health Organization.

\section{Acknowledgement}

This analytical research has been funded by Higher Education Quality Enhancement Project (HEQEP), Window II, Round III, CP 3245, University Grants Commission of Bangladesh.

\section{Authors' contributions}

SB and ASSR did the experimental design of this study. MSH and MSI performed the laboratory analyses. MSH, MSI, and SB interpreted the data. MSH wrote the manuscript. MSH, SB, and ASSR edited and proofread the manuscript. All authors read and approved the final manuscript.

\section{Competing interests}

The authors declare that they have no competing interests.

Received: 15 December 2015 Accepted: 20 July 2016

Published online: 05 August 2016

\section{References}

Ali ANAA. Application of responsive regulation in the food safety regulations of Bangladesh. J South Asian Stud. 2013;01(01):01-9.

Ayala J, Simons K, Kerrigan S. Quantitative determination of caffeine and alcohol in energy drinks and the potential to produce positive transdermal alcohol concentrations in human subjects. J Anal Toxicol. 2009;33(January/February):27-33.

Cempírková R, Mikulová M. Incidence of psychrotrophic lipolytic bacteria in cow's raw milk. Czech J Anim Sci. 2009:54(2):65-73.

Chanda T, Debnath GK, Hossain ME, Islam MA, Begum MK. Adulteration of raw milk in the rural areas of Barisal district of Bangladesh. Bangladesh J Anim Sci. 2012;41(2):112-5.

Craig WJ, Nguyen TT. Caffeine and theobromine levels in cocoa and carob products. J Food Sci. 1984;49(1):302-3.
Davies S, Lee T, Ramsey J, Dargan PI, Wood DM. Risk of caffeine toxicity associated with the use of 'legal highs' (novel psychoactive substances). Eur J Clin Pharm. 2012;68(4):435-9.

Dunn RO. Effect of antioxidants on the oxidative stability of methyl soyate (biodiesel). Fuel Processing Technol. 2005;86(10):1071-85.

FAO. Dairy production and products: Milk and milk products. 2013a. http://www.fao. org/agriculture/dairy-gateway/milk-and-milk products. Accessed 25 Dec 2014.

FAO. Dairy production and products: Milk processing. 2013b. http://www.fao.org/ agriculture/dairy-gateway/milk-processing. Accessed 25 Dec 2014.

Codex general standard for food additives 192-1995. Food and Agriculture Organization of the United Nations (FAO) and World Health Organization (WHO). 2015.

Grant DC, Helleur RJ. Simultaneous analysis of vitamins and caffeine in energy drinks by surfactant-mediated matrix-assisted laser desoprtion/ionization. Anal Bioanal Chem. 2008;391:2811-8.

Guizani N. Postharvest handling of milk. In: Rahman MS, editor. Handbook of food preservation. 2nd ed. New York: Taylor \& Francis Group; 2007.

Hossain MM, Heinonen V, Islam KMZ. Consumption of foods and foodstuffs processed with hazardous chemicals: a case study of Bangladesh. Int J Consumer Stud. 2008:32:588-95.

Injac R, Srdjenovic B, Prijatelj M, Boskovic M, Rajic KK, Strukelj B. Determination of caffeine and associated compounds in food, beverages, natural products, pharmaceuticals, and cosmetics by micellar electrokinetic capillary chromatography. J Chromatogr Sci. 2008;46(February):137-43.

Kerrigan S, Lindsey T. Fatal caffeine overdose: two case reports. Forensic Sci Int. 2005;153(1):67-9.

Khosrokhavar R, Sadeghzadeh N, Amini M, Ghazi-Khansari M, Hajiaghaee R, Sh EM. Simultaneous determination of preservatives (sodium benzoate and potassium sorbate) in soft drinks and herbal extracts using high performance liquid chromatography (HPLC). J Med Plants. 2010;9(35):80-7.

King RL. Oxidation of milk fat globule membrane material. I. Thiobarbituric acid reaction as a measure of oxidized flavor in milk and model systems. J Dairy Sci. 1962;45(10):1165-71.

Lee MR, Lin CY, Li ZG, Tsai TF. Simultaneous analysis of antioxidants and preservatives in cosmetics by supercritical fluid extraction combined with liquid chromatography-mass spectrometry. J Chromatogr A. 2006;1120(1-2): 244-51.

Medeiros RA, Rocha-Filho RC, Fatibello-Filho O. Simultaneous voltammetric determination of phenolic antioxidants in food using a boron-doped diamond electrode. Food Chem. 2010;123(3):886-91.

Mihyar GF, Yousif AK, Yamani MI. Determination of benzoic and sorbic acids in labaneh by high-performance liquid chromatography. J Food Composit Anal. 1998;12:53-61.

Mroueh M, Issa D, Khawand J, Haraty B, Malek A, Kassaify Z, Toufeili I. Levels of benzoic and sorbic acid preservatives in commercially produced yoghurt in Lebanon. J Food Agri Environ. 2008;6(1):62-6.

[NFSL] The National Food Safety Laboratory. UN-FAO-backed lab finds chemicals in Bangladeshi food. 2014. http://www.bdfoodsafety.org/state-halts-raw-milksales-from-idaho-dairy. Accessed 10 April 2016.

Nutri pro. Caffeine. Nestle professional. 2013. http://www.nestleprofessional. com/australia/en/Insights/Nutrition-Fact-Sheets/Pages/Caffeine. Accessed 16 May 2013.

Pattono D, Battaglini LM, Barberio A, Castelli LD, Valiani A, Varisco G, Scatassa ML, Davit P, Pazzi M, Civera T. Presence of synthetic antioxidants in organic and conventional milk. Food Chem. 2009;115:285-9.

Petronela CENE, Elena DIACU. High-performance liquid chromatography method for the determination of benzoic acid in beverages. U P B Sci Bull B. 2009; 71(4):81-8

Potter NN, Hotchkiss JH. Food Science. In: Potter NN, editor. Food Deterioration and its Control. 5th ed. New York: Springer; 1999.

Qi P, Hong H, Liang X, Liu D. Assessment of benzoic acid levels in milk in China. Food Control. 2008;20:414-8.

Rahman MM, Kabir SML. Developing awareness profiling force and activities linking safety and quality of foods of animal origin in Bangladesh. Scient J Review. 2012;1(3):84-104.

Report on carcinogens. BHA. National Toxicology Program, Department of Health and Human Services. 2014. https://ntp.niehs.nih.gov/ntp/roc/content/profiles/ butylatedhydroxyanisole.pdf. Accessed 16 May 2013.

Roye RC, Sheskey PJ, Quinn ME. Handbook of pharmaceutical excipients. In: Roye RC, Sheskey PJ, Quinn ME, editors. Pharmaceutical Press, London and American Pharmacists Association, Washington. 6th ed. 2009. 
Saad B, Bari MF, Saleh MI, Ahmad K, Khairuddin M, Talib M. Simultaneous determination of preservatives (benzoic acid, sorbic acid, methylparaben and propylparaben) in foodstuffs using high-performance liquid chromatography. J Chromatogr A. 2005;1073:393-7.

Sather K, Vernig T. Determination of caffeine and vitamin B6 in energy drinks by high-performance liquid chromatography (HPLC). Concordia College J Anal Chem. 2011;2:84-91.

Simmons CRF, Kidner N. Caffeine toxicity in a bodybuilder. Emerg Med J. 1998;15: 196-7. doi:10.1136/emj.15.3.196

Srdjenovic B, Milic VD, Grujic N, Injac R, Lepojevic Z. Simultaneous HPLC determination of caffeine, theobromine, and theophylline in food, drinks, and herbal products. J Chromatogr Sci. 2008;46(February):144-9.

Tang Y, Wu M. The simultaneous separation and determination of five organic acids in food by capillary electrophoresis. Food Chem. 2007;103(1):243-8.

Tawalbeh Y, Ajo R, Al-Udatt M, Gammoh S, Maghaydah S, Al-Qudah Y, Al-Sunnaq A, Al-Natour F. Investigation of the antimicrobial preservatives in the dairy product (labneh). Food Sci Qual Management. 2014;31:117-21.

Tfouni SAV, Toledo MCF. Determination of benzoic and sorbic acids in Brazilian food. Food Control. 2002;13:117-23.

Varga L. Microbiological quality of commercial dairy products. 2007. Formatex, http://www.formatex.org/microbio/papers.htm. Accessed 26 July 2016.

[WHO] World Health Organization. Propylparaben. 2010. http://apps.who.int/foodadditives-contaminants-jecfa-database/chemical.aspx?chemID $=330$. Accessed 16 May.

Yang MH, Lin HJ, Choong YM. A rapid gas chromatographic method for direct determination of BHA, BHT and TBHQ in edible oils and fats. Food Res Int. 2002;35(7):627-33.

\section{Submit your manuscript to a SpringerOpen ${ }^{\odot}$ journal and benefit from:}

- Convenient online submission

- Rigorous peer review

- Immediate publication on acceptance

- Open access: articles freely available online

- High visibility within the field

- Retaining the copyright to your article

Submit your next manuscript at $\gg$ springeropen.com 